If you would like to update your corporate image, promote your product or service, or have an educational or training film made by a competent and imaginative team of professionals, read on.

Blackwell Videotec has years of experience in the corporate video world, specialising in the technical, scientific and research areas.

To support the film or video we also offer a full publishing service under the BV-Blackwell name.

A member of the Oxford based Blackwell publishing group, our name guarantees an authoritative corporate presentation.

Blackwell Videotec Limited Film and Video Production 7 John Street London WC1N 2ES

Tel: $014300044 \quad 4301918$ Contact: Solomon Nwabueze

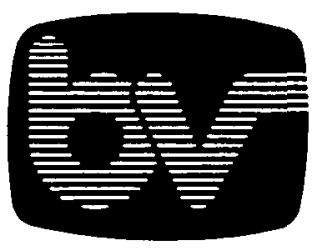

\title{
The Development of Anaesthetic Apparatus
}

\section{A history based on the Charles King Collection of the Association of Anaesthetists of Great Britain and Ireland}

\section{K. Bryn Thomas fFarcs}

From the reviews

'There is no other catalogue in the history of medicine akin to this one for it acts as a history of anaesthetics and of instrumental ingenuity, and at the same time is a scholarly guide to the artefacts themselves.' Medical History

'It has been well done, wonderfully illustrated, and is worthy of a medical historian of Dr Bryn Thomas's reputation.' British Medical Journal

'Serious work of scholarship though this is, Dr Bryn Thomas has enlivened it with many delightful asides ... and has included so much background material as to make it a treasure house of anaesthesiological information and lore catering for all tastes and prejudices.'

History of Medicine

1975. 280 pages, 233 illustrations. $£ 27.50$

0632001771

\section{Blackwell Scientific Publications}

Osney Mead, Oxford OX2 OEL, England 


\section{CAMBRIDGE}

\section{The Correspondence of Charles Darwin \\ VOLUME 2: $1837-184 \overline{3}$}

Edited by F. BURKHARDT and S. SMITH

The letters in this volume were written during the seven years following Darwin's return to England from the Beagle voyage. It was a period of extraordinary activity and productivity in which he became recognised as a naturalist of outstanding ability, as an author and editor, and as a professional man with official responsibilities in several scientific organisations. During these years he published two books and fifteen papers and he also organised and superintended the publication of The Zoology of the Voyage of the HMS Beagle. Busy as he was with scientific activities, Darwin found time to re-establish family ties and friendship, and married his cousin, Emma Wedgwood. In 1842, they moved to Down House, where Darwin was to spend the rest of his life. Viewed retrospectively, the most important of

Darwin's activities during the years $1837-1842$ was the development and first draft of his ideas on speciation.

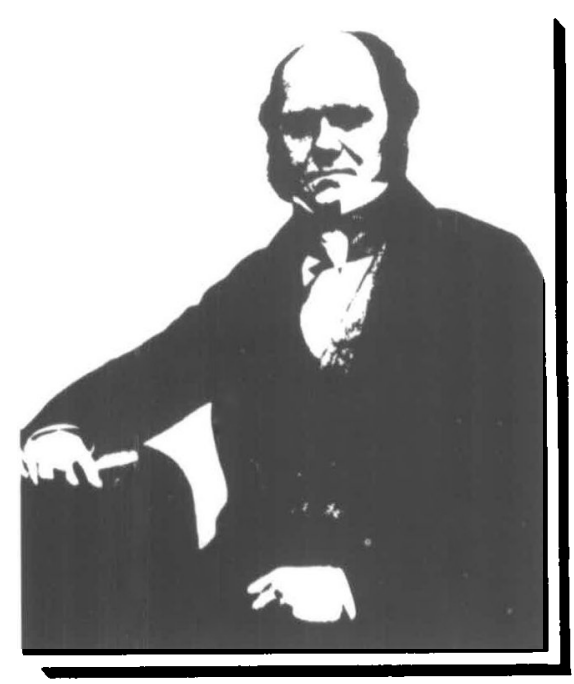

a most exacting work of scholarship... a consistently fascinating history of Darwin'

Sunday Times

'produced with the same devoted care as the first'

Nature

$1987640 p p .0521255880$

$\$ 30.00$ net

\section{Herbals}

Their Origin and Evolution. A Chapter in the History of Botany 1470-1670

\section{AGNES ARBER}

From 1470 to 1670 botany developed into a scientific discipline separate from herbalism and pharmacy and for that reason Arber's book has retained its interest and value and stands as the major survey. This reissue has a valuable introduction, annotations and a much expanded biographical guide by William T. Stearn. It also includes two important and related publications by Arber.

1987392 pp. $\quad 0 \quad 521338794$

Paperback $\$ 15.00$ net

\section{Introduction to the History of Medical and Veterinary Mycology}

\section{G. C. AINSWORTH}

This book is the first to give a well-documented illustrated survey of the historical background to diseases in man and domesticated animals which are caused by fungi. The history of research into this area is described as well as the organisms themselves. It includes the study of infectious diseases caused by actinomycetes.

$1986228 p$ p. O 521307155

\$30.00 net

For further information on these titles please contact Shelby Howe at the address below.

\section{Cambridge University Press}




\section{Science Progress}

\section{a review journal of current scientific advance}

\section{EDITORS}

\section{Professor J.M. Ziman FRS}

Departments of Social and Economic Studies and of Humanities, Imperial College, London

\section{Professor P.J.B. Slater}

Department of Zoology and Marine Biology, University of St Andrews

\section{Professor Patricia Clarke FRS}

\section{Cirencester}

Science Progress was first published in 1894, and its primary object has always remained the same - to publish articles written by experts to explain the latest developments in their own speciality to their colleagues working in other fields. Some of the most spectacular advances in science arise from the fusion of two or more disciplines, such as that of physics and chemistry with genetics to produce molecular biology. In this situation the journal's current practice of presenting non-specialist reviews is particularly valuable. It seeks as far as possible to emphasize current progress on the borderlines of the scientific disciplines in the hope that it may further the unification of science and stimulate scientists to think about problems outside their own immediate fields of interest.

\section{Subscription Information}

Science Progress is published quarterly. Subscription rates for 1987 are $£ 38.00$ (UK), $\$ 85.00$ (USA \& Canada), $£ 45.40$ (elsewhere) post free.

\section{Order Form}

Please tick the appropriate box and return to Blackwell Scientific Publications Ltd, P.o. Box 88, Oxford, England.

$\square$ I would like to subscribe to Science Progress

$\square$ I wish to pay by cheque/money order (delese as necessary) and enclose the sum of

$\square$ I wish to pay by Access/Barclaycard/VISA/Mastercard (delete as necessary)

Please debit my credit card no.

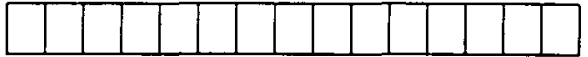

Expiry date with the sum of

Signature Date

Please send me a specimen copy of Science Progress

Name

Address

\section{Blackwell Scientific Publications}

P.O. BOX 88, Oxford, England 


\section{THE BRITISH SOCIETY FOR THE HISTORY OF SCIENCE}

Membership of the Society, which includes a subscription to The British Journal for the History of Science, is open to all persons approved by the Council of the Socicty and elected at an ordinary meeting (formalities required by the UK Companies Act). The annual subscription for the membership year 1986-1987 is $£ 13.5^{\circ}$ (US $\$ 27.00$ in the Americas, Canada and Japan) or for students, $\ell^{6.75}\left(\$ 13.5^{\circ}\right)$. Applications for membership should be made on a form which is available from the Socicty's Exccutive Secretary at the address below.

Meetings: The Society mounts an ambitious programme of meetings. The pattern is flexible, the only fixture being the three day summer meeting, held at a different British University or Polytechnic each year. About four other meetings, lasting for between one and threc days, are held during the year, sometimes devoted to a clearly-defined theme or an important anniversary, and often arranged in conjunction with other scholarly socictics.

The British Journal for the History of Science is the official organ of the Socicty. All correspondence on the contents of the Journal should be addressed to the Editor, Dr David Knight, Department of Philosophy, University of Durham, $5^{\circ}$ Old Elvet, Durham DH ${ }_{3} \mathrm{HN}$, England.

Books for review should be sent to the Reviews Editor, Dr John Hendry, 58 Canfield Gardens, London NW6 3 EB.

Advertising: Contact the Advertising Department, Blackwell Scientific Publications, Osney Mead, Oxford, OX2 oEL. Fax no. (0865) $72 \mathrm{I}_{20} 2$.

Other publications: BSHS Monograph Scries is designed to allow the publication of monographic studies in the history of science quickly and cheaply. All correspondence on the subject of monographs, and any new suggestions for titles, should be sent to the Series Editor, Dr.J. G. Smith, Department of History, University of Loughborough, Loughborough, Leics LE I I 3 TU, England. Monographs are available to members at a special price, post-free from the Society's Executive Secretary. Non-members may obtain them through bookshops, or post-free from the Executive Secretary. Now available:

1. Images of the Earth: Essays in the History of the Environmental Sciences. Ed. by L. J. Jordanova and Roy Porter. $1979 \cdot £ 7.50 / \$ 15.00$ ( $£ 5.00 / \$ 10.00$ to members).

2. The Letlers of Georges Cuvier: A Summary Calandar. Ed. by Dorinda Outram. Ig80. $\mathcal{L}_{4.50 / \$ 9.00}$ ( $£ 3.50 / \$ 7.00$ to members).

3. Rationality and Ritual: The Windscale Inquiry and Nuclear Decisions in Britain. By Brian Wynne. $£ 7.00 /$ \$14.00 (£5.00/\$1 0.00 to members).

4. The Royal Society and Its Fellows I660-I700: The Morphology of an Early Scientific Institution. By Michacl Hunter. $£ 9.00 / \$ 18.00$ ( $\AA^{6.5 \% / \$ 13.00 ~ t o ~ m e m b e r s) . ~}$

5. Francis Bacon's Natural Philosophy: A New Source. A Transcription of Manuscript Hardwick $72 A$ with Translation and Commentary. By Graham Rees, assisted by Christopher Upton. $£ 7.90 / \$ 15.5^{\circ}(£ 5.60 /$ \$i r.00 to members).

List of theses: Every December, the Society publishes a full list of current theses in history of science in British universities. This is available free to members, and at a small charge to non-members on request to the Executive Secretary. Standing orders are accepted from members or non-members who wish to receive the list regularly.

The Society's Nezesletter, an informal publication edited by Dr Mari Williams, Business History Unit, Lionel Robbins Building, to Portugal Street, London $W_{2} \mathrm{~A}_{2} \mathrm{HD}$, appears in January, May and Scptember each year. It is frec to members, $£ 4.5^{\circ}$ for institutions and non-members.

All the administrative business of the Society is handled by The Exccutive Secretary, WingCommander G. Bennett, 'Southide', 31 High Street, Stanford-in-the-Vale, Faringdon, Oxfordshire $\mathrm{SN}_{7} 8 \mathrm{LH}$. 


\section{July I 987}

24I Isobel Falconer: Corpuscles, Electrons and Cathode Rays: J. J. Thomson and the 'Discovery of the Electron'

287 Maurice Crosland: The Image of Science as a Threat: Burke versus Priestley and the 'Philosophic Revolution'

319 James R. Hofmann: Ampère's Invention of Equilibrium Apparatus: A Response to Experimental Anomaly

353 H. A. M. Snelders: History of Science Today, 2. History of Science in the Netherlands

\section{Obituaries}

359 Joan Mary Eyles, née Biggs: i 907-1986

$360 \quad$ Niels Hugh de Vaudrey Heathcote: 22 January I 895-23June I 985

363 Book Reviews

37I Books Received

\section{Published for The British Society for the History of Science}

by Blackwcll Scientific Publications

Oxford $\cdot$ London $\cdot$ Edinburgh $\cdot$ Boston $\cdot$ Palo Alto $\cdot$ Melbourne 